\title{
EVALUATION AND COMPARATIVE STUDY OF HYPOGLYCAEMIC ACTIVITY OF MORUS ALBA WITH ORAL HYPOGLYCAEMIC DRUG (GLIBENCLAMIDE) IN ALLOXAN INDUCED DIABETIC RATS
}

\author{
Naveen Kumar Madalageri1, Lavanya Nagaraj², Suryanarayana Babushaw Nidamarthi ${ }^{3}$ \\ ${ }^{1}$ Assistant Professor, Department of Pharmacology, Sree Narayana Institute of Medical Sciences, Ernakulam, Kerala. \\ ${ }^{2}$ Assistant Professor, Department of Pharmacology, Sree Narayana Institute of Medical Sciences, Ernakulam, Kerala. \\ 3Professor \& HOD, Department of Pharmacology, Educare Institute of Dental Sciences, Chattiparamba, Malappuram, Kerala.
}

\begin{abstract}
Diabetes mellitus is a metabolic disorder due to relative or absolute lack of insulin, resulting in elevated blood glucose levels in association with long-term vascular and neurological complications. Despite the availability of many antidiabetic medicines in the market, diabetes and its related complications continue to be major medical problems. The currently used hypoglycaemic drugs in the treatment of diabetes are not completely effective and are associated with adverse effects both in the short and long run. Some studies have reported many different medicinal properties of mulberry leaves (Morus alba) like neuroprotective property, cardioprotective property, anti-depressant property. It is used as an anti-inflammatory, diuretic, expectorant and antidiabetic in traditional Chinese medicine. So this study is undertaken to evaluate the hypoglycaemic effect of aqueous extract of leaves of Morus alba in Alloxan induced diabetic albino rats.
\end{abstract}

\section{OBJECTIVES}

- To study the hypoglycaemic activity of Morus alba in Alloxan induced model of diabetes in albino rats.

- To compare the hypoglycaemic activity of Morus alba with that of standard drug Glibenclamide.

\section{METHODS}

Total 24 albino rats of either sex weighing 150-200 gms were selected and randomly divided into 4 equal groups containing 6 rats in each group. First group (Non-diabetic control) was given normal saline $(0.5 \mathrm{~mL})$. Other 3 groups were induced diabetes by giving Alloxan (150 mg/kg ip). They were subdivided into diabetic control group receiving normal saline $(0.5 \mathrm{~mL})$, standard control group receiving Glibenclamide $(0.5 \mathrm{mg} / \mathrm{kg}$ body weight) and test group receiving Morus alba extract ( $600 \mathrm{mg} / \mathrm{kg})$. Fasting blood sugar level was estimated on day $0,1,3,7,14,21$ and 28 by using glucometer. Data were statistically analysed by Tukey's Post Hoc test and ANOVA.

\section{RESULTS}

Morus alba at the above doses significantly reduced blood glucose levels as compared to control group ( $\mathrm{p}<0.01)$, but as compared to standard drugs (Glibenclamide) it is statistically insignificant ( $\mathrm{p}>0.05)$.

\section{CONCLUSION}

The result suggests that Morus alba leaves have hypoglycaemic activity.

\section{KEYWORDS}

Morus Alba, Alloxan, Hypoglycaemia, Glibenclamide, Albino Rats.

HOW TO CITE THIS ARTICLE: Madalageri NK, Nagaraj L, Nidamarthi SB. Evaluation and comparative study of hypoglycaemic activity of morus alba with oral hypoglycaemic drug (glibenclamide) in alloxan induced diabetic rats. J. Evolution Med. Dent. Sci. 2016; 5(48):3062-3065, DOI: 10.14260/jemds/2016/713

\section{INTRODUCTION}

Diabetes mellitus is a metabolic disorder due to relative or absolute lack of insulin, resulting in elevated blood glucose levels in association with long-term vascular and neurological complications. ${ }^{1}$

Once regarded as a single disease entity, diabetes mellitus is now seen as heterogeneous group of diseases characterized by a state of chronic hyperglycaemia resulting from a diversity of aetiologies, environmental and genetic factors acting jointly.

Financial or Other, Competing Interest: None.

Submission 29-04-2016, Peer Review 23-05-2016,

Acceptance 30-05-2016, Published 15-06-2016.

Corresponding Author:

Dr. Naveen Kumar Madalageri,

Assistant Professor,

Department of Pharmacology,

Sree Narayana Institute of Medical Science,

Chalakka, Ernakulam-683594,

Kerala.

E-mail: dr.naveen.madalageri@gmail.com

DOI: $10.14260 /$ jemds/2016/713
Chronic hyperglycaemia leads to number of complicationscardiovascular, renal, neurological, ocular and others such as intercurrent infections. ${ }^{2}$

Currently, Insulin and Oral hypoglycaemic agents like Sulfonylureas and Biguanides are main treatment modalities of diabetes. Despite the availability of many antidiabetic medicines in the market, diabetes and its related complications continue to be major medical problems. The currently used hypoglycaemic drugs in the treatment of diabetes are not completely effective and are associated with adverse effects both in the short and long run. ${ }^{3}$

Plant derivatives with purported hypoglycaemic properties are used in folk medicine and traditional healing systems around the world. The antihyperglycaemic effects of these plants are attributed to their ability to increase insulin output from the pancreas or inhibit intestinal absorption of glucose or some other processes. ${ }^{4}$

Some studies have reported many different medicinal properties of mulberry leaves (Morus alba) like neuroprotective property, cardioprotective property, 
antidepressant property.5,6,7 It is used as anti-inflammatory, diuretic, expectorant and antidiabetic in traditional Chinese medicine. ${ }^{8,9,10}$

So this study is undertaken to evaluate the hypoglycaemic effect of aqueous extract of leaves of Morus alba in Alloxan induced diabetic albino rats.

\section{METHODOLOGY}

The study was conducted at Department of Pharmacology, J. J. M. Medical College, Davangere, after the approval from Institutional Animal Ethics Committee.

\section{MATERIALS}

\section{Animals}

Animals used were albino rats, of Wistar strain, weighing between 150-200 gm of either sex.

\section{CHEMICALS}

1. Alloxan Monohydrate: Alloxan monohydrate dissolved in $0.9 \%$ sodium chloride solution (normal saline) is used in this study.

2. Sodium Chloride: It is used to prepare normal saline in distilled water.

3. Glibenclamide: Glibenclamide belongs to second generation sulfonylureas. In this study, it is taken as the standard drug and results are compared with test drug.

4. Morus Alba: The aqueous extract of leaves was procured from Natural remedies, Bangalore. The extract was used at doses of $600 \mathrm{mg} / \mathrm{kg}$. The solution was freshly prepared by dissolving the aqueous extract in normal saline on the day of experiment and administered by oral route.

\section{Equipment}

1. Rat Feeding Needle: Metallic feeding tube used for oral administration of the drugs.

2. Tuberculin Syringe: Used for injecting Alloxan into peritoneal cavity and for administering the drug at proper dosage.

3. Insulin Syringe: For drawing blood from tail vein of rats.

4. Glucometer: The glucometer used in this study is the Optium Xceed Sensor from Abbott Diabetes Care Ltd.

\section{METHODS}

\section{Inclusion Criteria}

- Animals weighing 150-200 gms.

- Age 3-4 months.

- Healthy with normal behaviour and activity.

\section{Exclusion Criteria}

- Animals weighing more than 200 gms and less than 150 gms.

- Age $<3$ months and $>4$ months.

- Pregnant females and those which have delivered.

In the present study, diabetes was chemically induced using Alloxan to produce hyperglycaemia in rats. Here the Alloxan monohydrate was administered intraperitoneally under aseptic precaution to induce diabetes mellitus 5 days before the experiment. The blood glucose was measured with the help of Glucometer.

A total of 24 animals ( $n=24)$ were used. They were divided into 4 groups of 6 animals each. They were housed in cages containing wooden shavings with 6 animals per cage. Animals were randomly housed at a controlled temperature of $21 \pm$ $3{ }^{\circ} \mathrm{C}$, with a 12 -hour light: 12 -hour dark cycle. The animals had free access to standard pellet and water. Out of 24 rats, 18 rats were induced diabetes.

\section{Induction of Diabetes}

Following an overnight fast, 18 rats were injected intraperitoneally with freshly prepared Alloxan monohydrate ( $2 \%$ solution, dissolved in $0.9 \%$ sodium chloride) in a dose of $150 \mathrm{mg} / \mathrm{kg}$ body weight.

Animals were carefully observed for first 24 hours following the injection for any evidence of allergic reactions, behavioural changes, convulsions and hypoglycaemic attacks. No untoward reaction was observed in any animal.

Blood glucose level was recorded daily morning at around 9.00 a.m. for 1 week. Animals developed stable hyperglycaemia after 5 days. Only those animals with blood glucose level more than $250 \mathrm{mg} / \mathrm{dL}$ were selected for the study. Later they were divided into 3 groups: Diabetic control group, Standard control group, and Test group. Animals which were not given Alloxan to induce diabetes were considered as Non-diabetic control group.

\section{They were divided into four groups as follows Non-diabetic Control Group (Group 1):}

Here, non-diabetic normal animals which have not received Alloxan were taken as control group for study. Animals were fed with $0.5 \mathrm{~mL}$ of normal saline daily for 28 days through oral route. Blood glucose levels were recorded on 0 day before the administration of normal saline, then on $1^{\text {st }}, 3^{\text {rd }} 7^{\text {th }}, 14^{\text {th }}, 2^{\text {st }}$ and $28^{\text {th }}$ days.

\section{Diabetic Control Group (Group 2)}

The blood glucose levels of diabetic animals of this group were recorded at around 9 am before giving normal saline. This value was considered as blood glucose value of 0 day. Later the animals were fed with $0.5 \mathrm{~mL}$ normal saline orally, daily in the morning for 28 days. Blood glucose levels were recorded on $1^{\text {st }}, 3^{\text {rd }}, 7^{\text {th }}, 14^{\text {th }}, 21^{\text {st }}$, and $28^{\text {th }}$ days. Animals were observed carefully for the evidence of any behavioural changes, hyperglycaemia, convulsions, etc.

\section{Standard Group (Group 3)}

The blood glucose levels of diabetic animals of this group were recorded at around 9 am before the administration of the standard drug Glibenclamide in a dose of $0.5 \mathrm{mg} / \mathrm{kg}$ body weight suspended in normal saline orally. This value was considered as blood glucose value of 0 day. Later the animals were fed with Glibenclamide $5 \mathrm{mg} / \mathrm{kg}$ body weight suspended in normal saline orally, daily in the morning for 28 days. Blood glucose levels were recorded on $1^{\text {st }}, 3^{\text {rd }}, 7^{\text {th }}, 14^{\text {th }}, 21^{\text {st }}$ and $28^{\text {th }}$ days. Animals were observed carefully for the evidence of any behavioural changes, hypoglycaemia, convulsions, etc.

\section{Test Group (Group 4)}

The blood glucose levels of diabetic animals of this group were recorded at around 9 am before the administration of the test drug Morus alba $600 \mathrm{mg} / \mathrm{kg}$ body weight suspended in normal saline; this value was considered as blood glucose value of 0 day. Later the animals were fed with Morus alba extract in a 
dose of $600 \mathrm{mg} / \mathrm{kg}$ body weight, daily in the morning for 28 days. Blood glucose levels were recorded on $1^{\text {st }} 3^{\text {rd, }} 7^{\text {th }}, 14^{\text {th }}$, $21^{\text {st }}$ and $28^{\text {th }}$ days. Animals were observed carefully for the evidence of any behavioural changes, hypoglycaemia and convulsions.

\section{RESULTS}

\begin{tabular}{|c|c|c|c|c|c|c|c|}
\hline Groups & D0 & D1 & D3 & D7 & D14 & D21 & D28 \\
\hline 1. Non-Diabetic Control & $63.0 \pm 8.4$ & $62.0 \pm 7.2$ & $63.3 \pm 8.5$ & $59.7 \pm 7.5$ & $62.3 \pm 6.1$ & $62.0 \pm 7.7$ & $67.7 \pm 6.6$ \\
\hline 2. $\quad$ Diabetic Control & $285.3 \pm 11.8$ & $288.7 \pm 15.7$ & $290.0 \pm 11.9$ & $292.7 \pm 11.8$ & $295.0 \pm 11.8$ & $295.0 \pm 11.2$ & $299.0 \pm 13.6$ \\
\hline $\begin{array}{l}\text { 3. Standard Group } \\
\text { (Glibenclamide) }\end{array}$ & $292.7 \pm 12.9$ & $282.3 \pm 11.4$ & $275.3 \pm 10.6$ & $270.3 \pm 10.8$ & $268.7 \pm 11.4$ & $264.7 \pm 11.2$ & $259.7 \pm 7.7$ \\
\hline 4. Test Group Morus Alba 0 & $288.3 \pm 14.3$ & $277.7 \pm 16.2$ & $271.0 \pm 13.6$ & $263.7 \pm 12.9$ & $258.7 \pm 12.9$ & $250.0 \pm 8.3$ & $247.0 \pm 6.5$ \\
\hline $\begin{array}{l}\text { Gr. } 1 \text { (Control) v/s } \\
\text { Gr. } 2,3,4\end{array}$ & $P=0.000$ & $P=0.000$ & $\mathrm{P}=0.000$ & $P=0.000$ & $\mathrm{P}=0.000$ & $P=0.000$ & $P=0.000$ \\
\hline
\end{tabular}

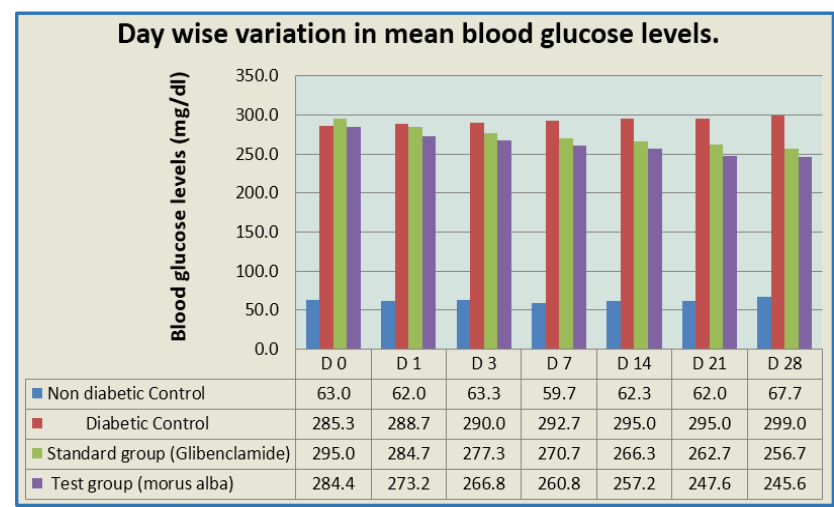

Graph 1: Bar Diagram showing Day Wise Variation in Mean Blood Glucose Levels in Various Study Groups
Table 1 and Graph 1 shows the variation in blood glucose levels on day 1 to day 28 in each group. Mean blood glucose levels in non-diabetic control group varied from 59.7 to 67.7 $\mathrm{mg} / \mathrm{dL}$ without much of variation during the study.

In diabetic control group, there was a gradual increase in blood glucose levels from mean value of $285.3 \pm 11.3 \mathrm{mg} / \mathrm{dL}$ on day 0 to $299.0 \pm 13.6 \mathrm{mg} / \mathrm{dL}$ on day 28 .

In standard group (Glibenclamide), there was gradual decrease in blood glucose level from $292 \pm 12.9 \mathrm{mg} / \mathrm{dL}$ on day 0 to $259.7 \pm 7.7 \mathrm{mg} / \mathrm{dL}$ on day 28 .

In test group, there was gradual decrease in blood glucose level from $288.3 \pm 14.3$ on day 0 to $247 \pm 6.5$ on day 28 , which was statistically significant compared to control.

\begin{tabular}{|c|c|c|c|c|c|c|c|}
\hline Groups & D0 & D1 & D3 & D7 & D14 & D21 & D28 \\
\hline 1. Diabetic control & $285.3 \pm 11.8$ & $288.7 \pm 15.7$ & $290.0 \pm 11.9$ & $292.7 \pm 11.8$ & $295.0 \pm 11.8$ & $295.0 \pm 11.2$ & $299.0 \pm 13.6$ \\
\hline $\begin{array}{ll}\text { 2. } & \text { Standard group } \\
\text { (Glibenclamide) }\end{array}$ & $292.7 \pm 12.9$ & $282.3 \pm 11.4$ & $275.3 \pm 10.6$ & $270.3 \pm 10.8$ & $268.7 \pm 11.4$ & $264.7 \pm 11.2$ & $259.7 \pm 7.7$ \\
\hline $\begin{array}{ll}3 . & \text { Test group } \\
& \text { (Morus alba) }\end{array}$ & $288.3 \pm 14.3$ & $277.7 \pm 16.2$ & $271.0 \pm 13.6$ & $263.7 \pm 12.9$ & $258.7 \pm 12.9$ & $250.0 \pm 8.3$ & $247.0 \pm 6.5$ \\
\hline F- Value & .480 & .861 & 4.065 & 9.850 & 14.512 & 29.714 & 45.975 \\
\hline Significance & $\mathrm{P}=0.628 \mathrm{NS}$ & $\mathrm{P}=0.443 \mathrm{NS}$ & $\mathrm{P}=0.039 \mathrm{~S}$ & $\mathrm{P}=0.002 \mathrm{~S}$ & $\mathrm{P}=0.000 \mathrm{~S}$ & $\mathrm{P}=0.000 \mathrm{~S}$ & $\mathrm{P}=0.000 \mathrm{~S}$ \\
\hline \multicolumn{8}{|c|}{$\begin{array}{l}\text { Table 2: Statistical Analysis Showing Comparison Of Mean Blood Glucose } \\
\text { Levels Between Different Groups On Different Days By Using One Way ANOVA Test }\end{array}$} \\
\hline
\end{tabular}

\begin{tabular}{|c|c|c|c|}
\hline \multirow{2}{*}{ Days } & $\begin{array}{c}\text { Groups } \\
\text { Compared }\end{array}$ & Mean Diff. & P - value* \\
\hline \multirow{3}{*}{0} & $2-3$ & -7.3333 & $.604, \mathrm{NS}$ \\
\cline { 2 - 4 } & $2-4$ & -3.0000 & $.917, \mathrm{NS}$ \\
\cline { 2 - 4 } & $3-4$ & 4.3333 & $.835, \mathrm{NS}$ \\
\hline \multirow{3}{*}{1} & $2-3$ & 6.3333 & $.737, \mathrm{NS}$ \\
\cline { 2 - 4 } & $2-4$ & 11.0000 & $.413, \mathrm{NS}$ \\
\cline { 2 - 4 } & $3-4$ & 4.6667 & $.846, \mathrm{NS}$ \\
\hline \multirow{3}{*}{3} & $2-3$ & 14.6667 & $.123, \mathrm{NS}$ \\
\cline { 2 - 4 } & $2-4$ & $19.0000^{*}$ & $.040, \mathrm{~S}$ \\
\hline \multirow{3}{*}{7} & $3-4$ & 4.3333 & $.811, \mathrm{NS}$ \\
\cline { 2 - 4 } & $2-3$ & 22.3333 & $.014, \mathrm{~S}$ \\
\cline { 2 - 4 } & $2-4$ & 29.0000 & $.002, \mathrm{~S}$ \\
\hline \multirow{3}{*}{14} & $3-4$ & 6.6667 & $.604, \mathrm{NS}$ \\
\cline { 2 - 4 } & $2-3$ & 26.3333 & $.005, \mathrm{~S}$ \\
\cline { 2 - 4 } & $2-4$ & 36.3333 & $.000, \mathrm{~S}$ \\
\hline 21 & $3-4$ & 10.0000 & $.349, \mathrm{NS}$ \\
\hline \multirow{2}{*}{21} & $2-3$ & 30.3333 & $.000, \mathrm{~S}$ \\
\hline
\end{tabular}

\begin{tabular}{|c|c|c|c|}
\hline & $2-4$ & $45.0000^{*}$ & $.000, \mathrm{~S}$ \\
\hline & $3-4$ & 14.6667 & $.064, \mathrm{NS}$ \\
\hline \multirow{3}{*}{28} & $2-3$ & 39.3333* & $.000, \mathrm{~S}$ \\
\hline & $2-4$ & $52.0000^{*}$ & $.000, \mathrm{~S}$ \\
\hline & $3-4$ & 12.6667 & $.097, \mathrm{NS}$ \\
\hline & $\begin{array}{l}\text { s on } \\
\text { Pos }\end{array}$ & $\begin{array}{l}\text { ays by U } \\
\text { 's Test }\end{array}$ & $\begin{array}{l}\text { rison of } \\
\text { rent }\end{array}$ \\
\hline
\end{tabular}

Table 2-3 gives statistical analysis of the results on day 1 , $3,7,14,21$ and 28 using one-way ANOVA followed by Tukey's Post Hoc test. The ' $\mathrm{P}$ ' value of $<0.05$ was considered significant. In ANOVA test, comparison of mean blood glucose levels between the groups was significant from day 3 till the end of study. In Post Hoc Tukey's test, comparison of mean reduction in blood glucose in test group (Morus alba) with that of diabetic control group was significant $(\mathrm{P}<0.05)$ from day three. 
However, with respect to standard control group (Glibenclamide), it was statistically insignificant $(\mathrm{P}>0.05)$.

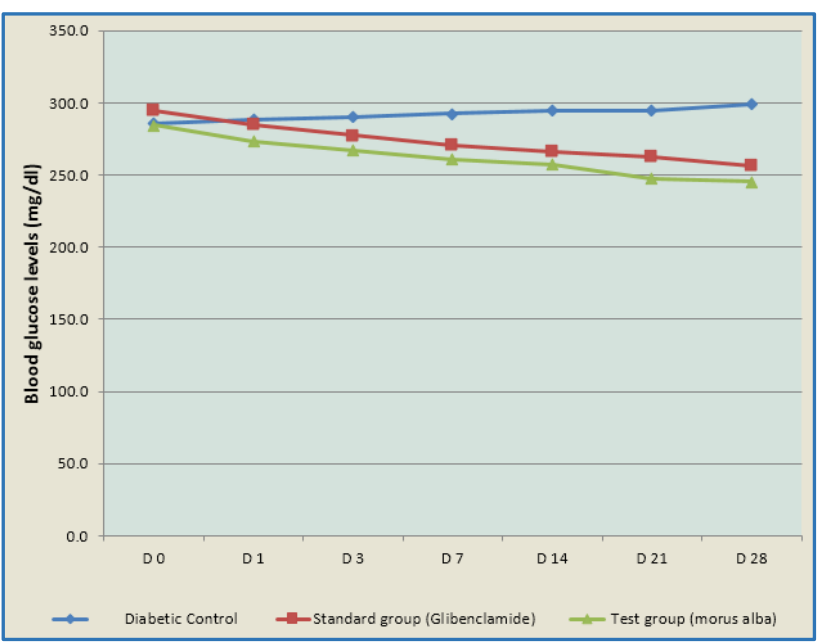

Graph 2: Line Diagram showing Variation in Blood Glucose Levels from Day 0 to Day 28 in Study Groups

Graph 2 shows comparison of mean blood glucose levels between standard and test groups, which are recorded in the fixed intervals as detailed in Table 1. It indicates that the test drug has similar hypoglycaemic action when compared to the standard group.

Overall mean percentage reduction of glucose was higher with test group (14.3\%) compared to standard control group (11.3\%).

\section{DISCUSSION}

In present study we have compared hypoglycaemic activity of Morus alba leaves extract with that of presently available oral hypoglycaemic drug Glibenclamide. Aqueous extract of Morus alba leaves $(600 \mathrm{mg} / \mathrm{kg})$ have decreased blood glucose level from $288.3 \mathrm{mg} / \mathrm{dL}$ on day 0 to $247.0 \mathrm{mg} / \mathrm{dL}$ on day 28 . Hypoglycaemia produced by Morus alba extract was significant $(\mathrm{p}<0.01)$ when compared to control group from day 3 to day 28. The percent reduction of blood glucose level during study period was $14.3 \%$ as compared to Glibenclamide group (11.3 \%). As compared to Glibenclamide group, Morus alba group has similar reduction in mean percent blood glucose level, but it was statistically insignificant ( $p>0.05)$.

The exact mechanism of hypoglycaemic activity of Morus alba is still unclear. It has been shown that methanolic extract of Morus alba leaf has hypoglycaemic activity and probably Morus alba has action on $\beta$ cells of pancreas. ${ }^{11}$ Morus alba leaves extract have significant inhibitory activity on $\alpha$ amylase enzyme. Hypoglycaemic action may be due to inhibition of $\alpha$ amylase enzyme or it could also be due to presence of Moran A and/or Moraline. ${ }^{12}$ However, the exact mode of action still needs to be elucidated and requires further studies in both animal models and in human subjects.

The present study has several limitations. Only the fasting blood glucose was estimated in this study, which does not give a clear picture about the effect of Morus alba on other parameters of diabetes mellitus. In present study, we have used single dose of $600 \mathrm{mg} / \mathrm{kg}$ as a testing dose. Further studies need to be done to fix proper dosage. Acute and chronic toxicity testing need to be undertaken. Sample size in the present study is small, hence further study needed to confirm the outcome of the present study.

\section{ACKNOWLEDGMENT}

We are thankful to Dr. Somashekar H.S., M.D., (Professor and H.O.D., Department of Pharmacology, JJMMC), Dr. H. S. Siddappa Devaru M.D., Dr. Nagabhushan A M.D., Dr. S. Y. Kattimani M.D., Dr. Shashikala G.H., M.D. (Professors of Pharmacology), Dr. Narendranath S., M.D., (Associate Professor in Pharmacology) Dr. Jyothi C.H., M.D., Dr. Geetha m.D. (Reader in Pharmacology), Dr. Suneel Kumar Reddy M.D., Dr. Kiran L.J., M.D., Dr. Shivshankar Murthy M.D. and Dr. Srinivas L.D., M.D. (Assistant Professors) for their kind support throughout the study. We are also thankful to Dr. Abhishek A, Dr. Prabhakar A and Dr. Gokul C.G. for their continuous cooperation during present study.

\section{REFERENCES}

1. Asha B, Krishnamurthy KH, Siddappa Devaru. Evaluation of anti-hyperglycaemic activity of zingiber officinale (Ginger) in albino rats. J Chem Pharm Res 2011;3(1):4526.

2. Park K. Diabetes mellitus. Parks textbook of preventive and social medicine, $18^{\text {th }}$ edi. Jabalpur: M/S Banarsidas Bhanot Publishers, 2005;312.

3. Babu V, Gangadevi T, Subramaniam A. Antihyperglycaemic activity of cassia kleinii leaf extract in glucose fed normal rats and alloxan induced diabetic rats. Indian J Pharmacol 2002;34:409-15.

4. Jamshid Mohammadi, Prakash R Naik. Evaluation of hypoglycaemic effect of morus alba in an animal model. Indian J Pharmacology 2008;40(1):15-8.

5. Kang TH, Oh HR, Jung SM, et al. Enhancement of neuroprotection of mulberry leaves (Morus alba L) prepared by the anaerobic treatment against ischemic damage. Biol Pharm Bull 2006;29(2):270-4.

6. Enkhmaa B, Shiwaku K, Katsube T, et al. Mulberry (Morus alba L) leaves and major flavonal quercetin 3-(6malonylglucaside) attenuate atherosclerotic lesion development in LDL receptor-deficient mice. J Nutr 2005;135(4):729-34.

7. Jintana Sattayasi, Siriporn Tiamkao, Prapawadee Puapairoj. Biphasic effect of morus alba leaves green tea extracton micein chronic forced swimming model. Phytother Res 2008;22(4):487-92.

8. Andallu B, Suryakantham V, Lakshmi B, et al. Effect of mulberry (Morus Indica L.) therapy on plasma and erythrocyte membrane lipids in patients with type 2 diabetes. Clin Chim Acta 2001;314(-2):47-53.

9. Andallu B, Varadacharyulu N. Control of hyperglycaemia and retardation of cataract by mulberry (Morus Indica L.) leaves in streptozotocin diabetic rats. Indian J Exp Biol 2002;40(7):791-5.

10. Andallu B, Varadacharyulu N. Antioxidant role of mulberry (Morus Indica L.cv. Anantha) leaves in streptozotocin diabetic rats. Clin Chim Acta 2003;338(12):3-10.

11. Arayne MS, Sultana N, Mirza AZ, et al. In vitro hypoglycaemic activity of methanolic extract of some indigenous plants. Pak J Pharm Sci 2007;20(4):268-73.

12. Bahman Nickavara, Golboo Mosazadeha. Influence of three morus species extracts on $\alpha$-amylase activity. Iranian Journal of Pharmaceutical Research 2009;8(2):115-9. 